Journal of Bangladesh Academy of Sciences, Vol. 37, No. 2, 231-243, 2013

\title{
WATER QUALITY OF SHALLOW TUBE WELLS AS AFFECTED BY SANITARY LATRINES AND GROUNDWATER FLOW
}

\author{
SYED HAFIZUR RAHMAN ${ }^{* 1}$, A.N.M. FAKHRUDDIN ${ }^{1}$, MOHAMMED JAMAL \\ UDDIN $^{1}$, MD. SHAHID ZAMAN ${ }^{1}$, ASISH TALUKDER ${ }^{1}$, TANVEER MEHEDI \\ ADYEL $^{2}$ AND MD. MIZANUR RAHMAN SARKER ${ }^{3}$ \\ Department of Environmental Sciences, Jahangirnagar University, Dhaka 1342, \\ Bangladesh
}

\begin{abstract}
The present study investigated the probable influence of latrines and groundwater flow on the water quality of shallow tube wells in Shinduria village (23.52' N and $\left.90^{\circ} 14^{\prime} \mathrm{E}\right)$ of Dhaka district, Bangladesh. A questionnaire survey was made to collect basic information on tube wells and latrines. Four boreholes were drilled to investigate lithostratigraphy. Twenty one water samples were collected and their physico-chemical parameters (Dissolved Oxygen, $\mathrm{pH}$, phosphate, sulphate, nitrate, nitrite and iron) were analyzed using standard method. Total viable bacterial count (TVBC), total coliform count (TCC), total faecal coliform count (TFCC), total salmonella shigella (TSS) and total vibrio count (TVC) were also made using membrane filtration method. Average depth of the tube wells was $120 \mathrm{ft}$ and most of them were less then ten years old. About $85 \%$ latrines were ring slab type and about $50 \%$ of these were built during the last five years. From borehole data, a shallow aquifer was identified at a depth of hundred feet from where local people extract drinking water. Although most of the physico-chemical parameters of the tested samples were within the Department of Environment (DoE). But almost all of the tested samples failed to ensure the quality of acceptable level for drinking water recommended by World Health Organization (WHO) due to the presence of higher load of TVBC $\left(5.07 \times 10^{3} \mathrm{cfu} / 100 \mathrm{ml}\right)$, TCC $\left(8.44 \times 10^{3} \mathrm{cfu} / 100 \mathrm{ml}\right)$, TFCC $\left(5.16 \times 10^{2} \mathrm{cfu} / 100 \mathrm{ml}\right)$ and TSS $\left(1.10 \times 10^{3} \mathrm{cfu} / 100 \mathrm{ml}\right)$. Local geological conditions and proximity between tube well and latrine promoted bacterial transport towards tube well while groundwater flow direction from the adjacent Bangshi River influenced the phenomenon.
\end{abstract}

Key words: Lithostatigraphy, Aquifer, Microbial load, Bangladesh

\section{INTRODUCTION}

Improper sanitation system is one of the major causes of microbial contamination and water-borne diseases in developing countries like Bangladesh (NIPORT 2005,

\footnotetext{
${ }^{*}$ Corresponding Author: <hafizsr@yahoo.com>.

${ }^{1}$ Department of Environmental Sciences, Jahangirnagar University, Dhaka 1342, Bangladesh.

${ }^{2}$ School of Environmental Systems Engineering, The University of Western Australia, 35 Stirling HYW, Crawley, WA 6009, Australia.

${ }^{3}$ Department of Geological Sciences, Jahangirnagar University, Dhaka 1342, Bangladesh.
} 
Rahman et al. 2009). Rural people use pit latrine which consists of a ditch in soil covered with a slab that contains a hole through which the feces enter into the pit. The solid waste remains within the pit, while the liquid waste percolates into the sub-soil via the permeable walls of the pit. Nearly half of the water samples collected from shallow tube wells in Bangladesh was contaminated with human faecal organisms (Islam et al. 2001, Luby et al. 2006, 2008). In general, latrines are closely located to shallow tube wells, which increase the possibilities of microorganisms to travel from pit to shallow aquifer. In Bangladesh, tube well water is used primarily as a source of drinking water by the vast majority (90\%) of the rural population and these tube wells have been installed at various depths, depending on availability and the level of groundwater. In many countries, waterborne diseases were linked to contaminated groundwater (Jones and Watkins 1985, Craun et al. 1997). Domestic sewage, effluent from septic tanks, pit latrines, soaks pits are the major sources contributing to groundwater contamination (Dwivedi et al. 2007, de Andrade et al. 2008, Ozler and Aydin 2008). Groundwater is generally safe owing to qualitative changes, especially in the high-density residential areas where sewage disposal practices are not proper (Blueford et al. 1996, Anand et al. 2006, Krishnan et al. 2007).

Moreover, groundwater flow from nearby water bodies and local lithostratigraphy may influence the physico-chemical and biological/bacterial properties of shallow tube well water. Therefore, the objective of this research was to investigate the probable influence of latrines and groundwater flow on the water quality of shallow tube wells in a rural village of Bangladesh.

\section{MATERIALS AND METHODS}

Shinduria $\left(23^{\circ} 52^{\prime} \mathrm{N}\right.$ and $\left.90^{\circ} 14^{\prime} \mathrm{E}\right)$, a rural village under Savar Upazilla of Dhaka district, Bangladesh was selected for the present study (Fig. 1). The Bangshi River is flowing along north-south direction at west side of the village. This uplifted Pleistocene terrace, one to 30 feet above the adjacent floodplains, comprises the south-western part of Madhupur Tract under the Tangail-Tripura High and is bounded by the Ganges floodplain in the east, the Brahmaputra floodplain in the north, the Jamuna floodplain in the west (Khandoker 1987).

A structured questionnaire was surveyed in 90 houses of the study area to gather information about tube wells types, its installation year, depth, types and characteristics of latrines. Four bore holes (up to $125 \mathrm{ft}$ ) (Table 1) were accomplished by wash borings method followed in Hand Dug technique of shallow wells. Drilling method prevents a complete evaluation of the finer grained fraction (commonly fine-grained sand and silt) that tends to be held in suspension by the drilling fluids. Lithologic descriptions are based on the criteria as (1) major textural class, (2) estimated grain-size distribution by major 
textural class: (A) silt-clay $(<0.05 \mathrm{~mm})(\mathrm{B})$ sand $(0.05-2.00 \mathrm{~mm})$ and $(\mathrm{C})$ gravel $(>2.00$ $\mathrm{mm})$, (3) grain and clast shape, (4) sorting and approximate range of grain and clast size, (5) clast composition and approximate relative abundance, in decreasing order of abundance, and (6) color using Munsell notation. At least $500 \mathrm{gm}$ sample at 0 - 20, 20 $60,60-80,80-100,100-125 \mathrm{ft}$ were kept in sterile poly bag, sealed, labeled with unique sample identity, brought to the laboratory and stored at ambient conditions prior to the analysis of lithologic features. Bore logs, 3D model and panel diagram of study area were modeled using Rockworks Software 2004. Groundwater flow direction of the study area was taken from available data and observations.
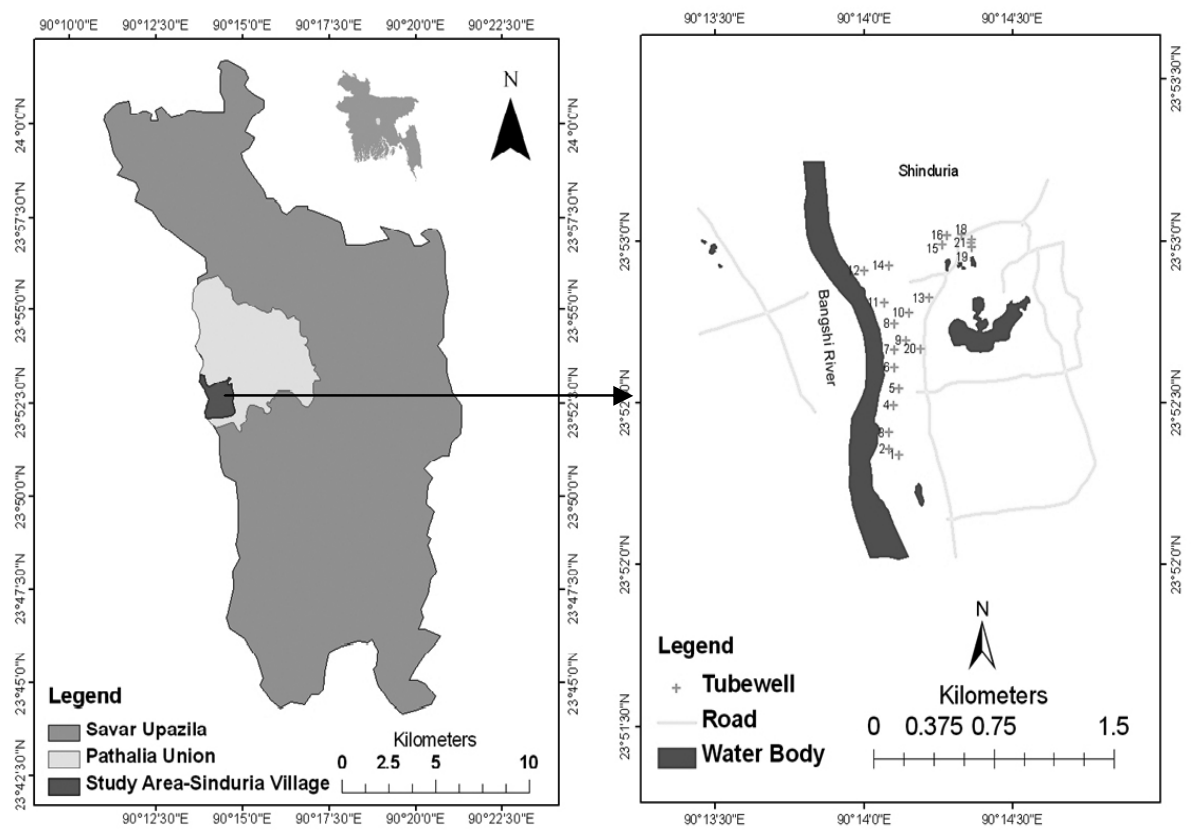

Fig. 1. Map of the study area indicating locations of shallow tube wells.

Water samples were collected from 21 shallow tube wells (triplicate of $1000 \mathrm{ml}$ from each sampling point) randomly throughout the study area (Table 1, Fig.1). pH and dissolved oxygen (DO) of the water samples were measured in situ using digital $\mathrm{pH}$ meter (SCOTTOH GERATE, Gmh, CG 818) and DO meter (Hanna Instrument Model No-9143), respectively. Colorimeter (DR/890 Hach Company, USA) was used to determine phosphate, sulphate, nitrate, nitrite and iron concentration using Molybdovanadate, SulfaVer 4, Nitraver 5, Nitriver 3 and FerroVer reagents of Hach Company, respectively. Detection and quantification of total viable bacterial count (TVBC), total coliform count (TCC), total faecal coliform count (TFCC), total Salmonella Shigella (TSS) and total vibrio count (TVC) were performed by Membrane 
filter (MF) technique using nutrient agar, Mac Conkey agar, $\mathrm{mFC}$ agar, SS agar and TCBS agar, respectively. TFCC plates were incubated at $44 \pm 0.5^{\circ} \mathrm{C}$ while others at $35 \pm 0.5^{\circ} \mathrm{C}$ for 24 hours. Number of colonies of each filter was calculated as colony forming units (cfu/100 ml).

Table 1. Account of shallow tube wells, their position to sanitary latrines and location of bore logs sites of the study area.

\begin{tabular}{|c|c|c|c|}
\hline $\begin{array}{l}\text { TW sample } \\
\text { No. }\end{array}$ & $\begin{array}{c}\text { Direction of SL } \\
\text { to } \mathrm{TW}\end{array}$ & GPS location of TW & GPS location of bore-log sites \\
\hline $\mathrm{T} 11$ & $\mathrm{~N} 85^{\circ} \mathrm{E}$ & $23^{\circ} 52^{\prime} 20^{\prime \prime} \mathrm{N} \& 90^{\circ} 14^{\prime} 07^{\prime \prime} \mathrm{E}$ & \\
\hline $\mathrm{T} 12$ & $\mathrm{~N} 15^{\circ} \mathrm{NE}$ & $23^{\circ} 52^{\prime} 21^{\prime \prime} \mathrm{N} \& 90^{\circ} 14^{\prime} 05^{\prime \prime} \mathrm{E}$ & \\
\hline T 20 & $\mathrm{~N} 235^{\circ} \mathrm{SW}$ & $23^{\circ} 52^{\prime} 24^{\prime \prime} \mathrm{N} \& 90^{\circ} 14^{\prime} 05^{\prime \prime} \mathrm{E}$ & \\
\hline Т 29 & $\mathrm{~N} 45^{\circ} \mathrm{NE}$ & $23^{\circ} 52^{\prime} 29^{\prime \prime} \mathrm{N} \& 90^{\circ} 14^{\prime} 06^{\prime \prime} \mathrm{E}$ & \\
\hline Т 33 & $\mathrm{~N} 190^{\circ} \mathrm{SW}$ & $23^{\circ} 53^{\prime} 01^{\prime \prime} \mathrm{N} \& 90^{\circ} 14^{\prime} 20^{\prime \prime} \mathrm{E}$ & \\
\hline T 34 & $\mathrm{~N} 310^{\circ} \mathrm{NW}$ & $23^{\circ} 52^{\prime} 58^{\prime \prime} \mathrm{N} \& 90^{\circ} 14^{\prime} 21^{\prime \prime} \mathrm{E}$ & \\
\hline T 36 & $\mathrm{~N} 210^{\circ} \mathrm{SW}$ & $23^{\circ} 53^{\prime} 01^{\prime \prime} \mathrm{N} \& 90^{\circ} 14^{\prime} 20^{\prime \prime} \mathrm{E}$ & \\
\hline Т 59 & $\mathrm{~N} 160^{\circ} \mathrm{SE}$ & $23^{\circ} 52^{\prime} 36^{\prime \prime} \mathrm{N} \& 90^{\circ} 14^{\prime} 06^{\prime \prime} \mathrm{E}$ & $\begin{array}{l}\text { L1: } 23^{\circ} 53^{\prime} 12.02^{\prime \prime} \mathrm{N} \& 90^{\circ} 13^{\prime} 27.02^{\prime \prime} \mathrm{E} \\
\text { L2: } 23^{\circ} 52^{\prime} 6.07^{\prime \prime} \mathrm{N} \& 90^{\circ} 13^{\prime} 27.09^{\prime \prime} \mathrm{E}\end{array}$ \\
\hline Т 60 & $\mathrm{~N} 39^{\circ} \mathrm{NE}$ & $23^{\circ} 52^{\prime} 32^{\prime \prime} \mathrm{N} \& 90^{\circ} 14^{\prime} 07^{\prime \prime} \mathrm{E}$ & L3: $23^{\circ} 52^{\prime} 5.95^{\prime \prime} \mathrm{N} \& 90^{\circ} 14^{\prime} 44.95 " \mathrm{E}$ \\
\hline $\mathrm{T} 88$ & $\mathrm{~N} 115^{\circ} \mathrm{SE}$ & $23^{\circ} 52^{\prime} 50^{\prime \prime} \mathrm{N} \& 90^{\circ} 14^{\prime} 13^{\prime \prime} \mathrm{E}$ & L4: $23^{\circ} 53^{\prime} 11.97 " \mathrm{~N} \& 90^{\circ} 14^{\prime} 45.05^{\prime \prime} \mathrm{E}$ \\
\hline Т 89 & $\mathrm{~N} 310^{\circ} \mathrm{NW}$ & $23^{\circ} 52^{\prime} 46^{\prime \prime} \mathrm{N} \& 90^{\circ} 14^{\prime} 09^{\prime \prime} \mathrm{E}$ & \\
\hline $\mathrm{T} 90$ & $\mathrm{~N} 40^{\circ} \mathrm{NE}$ & $23^{\circ} 52^{\prime} 49^{\prime \prime} \mathrm{N} \& 90^{\circ} 14^{\prime} 13^{\prime \prime} \mathrm{E}$ & \\
\hline $\mathrm{T} 91$ & $\mathrm{~N} 130^{\circ} \mathrm{SE}$ & $23^{\circ} 53^{\prime} 01^{\prime \prime} \mathrm{N} \& 90^{\circ} 14^{\prime} 20^{\prime \prime} \mathrm{E}$ & \\
\hline Т 92 & $\mathrm{~N} 130^{\circ} \mathrm{SE}$ & $23^{\circ} 52^{\prime} 59^{\prime \prime} \mathrm{N} \& 90^{\circ} 14^{\prime} 22^{\prime \prime} \mathrm{E}$ & \\
\hline Т 93 & $\mathrm{~N} 120^{\circ} \mathrm{SE}$ & $23^{\circ} 53^{\prime} 00^{\prime \prime} \mathrm{N} \& 90^{\circ} 14^{\prime} 22^{\prime \prime} \mathrm{E}$ & \\
\hline Т 94 & $\mathrm{~N} 250^{\circ} \mathrm{SW}$ & $23^{\circ} 53^{\prime} 01^{\prime \prime} \mathrm{N} \& 90^{\circ} 14^{\prime} 17^{\prime \prime} \mathrm{E}$ & \\
\hline Т 95 & $\mathrm{~N} 85^{\circ} \mathrm{SW}$ & $23^{\circ} 52^{\prime} 59^{\prime \prime} \mathrm{N} \& 90^{\circ} 14^{\prime} 16^{\prime \prime} \mathrm{E}$ & \\
\hline Т 96 & $\mathrm{~N} 270^{\circ} \mathrm{W}$ & $23^{\circ} 53^{\prime} 00^{\prime \prime} \mathrm{N} \& 90^{\circ} 14^{\prime} 16^{\prime \prime} \mathrm{E}$ & \\
\hline Т 97 & $\mathrm{~N} 40^{\circ} \mathrm{NE}$ & $23^{\circ} 52^{\prime} 58^{\prime \prime} \mathrm{N} \& 90^{\circ} 14^{\prime} 17^{\prime \prime} \mathrm{E}$ & \\
\hline Т 98 & $\mathrm{~N} 25^{\circ} \mathrm{NE}$ & $23^{\circ} 52^{\prime} 58^{\prime \prime} \mathrm{N} \& 90^{\circ} 14^{\prime} 17^{\prime \prime} \mathrm{E}$ & \\
\hline Т 99 & $\mathrm{~N} 60^{\circ} \mathrm{NE}$ & $23^{\circ} 52^{\prime} 59^{\prime \prime} \mathrm{N} \& 90^{\circ} 14^{\prime} 18^{\prime \prime} \mathrm{E}$ & \\
\hline
\end{tabular}

TW: Tube well; SL: Sanitary latrine; $L=$ Bore $\log$

Colony Forming Units per $100 \mathrm{ml}$ water $=$ No. of Colonies counted on membrane filter X 100 / Sample volume filtered (ml)

\section{RESULTS AND DISCUSSION}

Questionnaire survey revealed that among the studied 21 shallow tube wells, nine were 6-10 years old while only one was just over 15 years. The maximum tube wells (12) 
were about 100-150 ft deep in the study area. $85 \%$ latrines were ring slab type and about $50 \%$ of these were built during the last 5 years. Depth of sanitary latrines varied from 2 to $30 \mathrm{ft}$. The maximum latrines had a depth of 11-20 ft, while 6-10 ft was the common distance of 12 sanitary latrines from the adjacent tube wells. 1 tube well was located toward east, 7 toward north-east and 5 toward south-east, 5 towards south-west, 1 toward west and 2 toward north-west direction of the adjacent latrines. Overall scenario and status of tube wells and latrines of the studied area is illustrated in Table 2.

Table 2. Inventory of tube wells and latrines of Shinduria Village.

\begin{tabular}{|c|c|c|c|c|c|c|}
\hline $\begin{array}{c}\text { TW } \\
\text { sample }\end{array}$ & $\begin{array}{c}\text { Depth of } \\
\text { TW(ft) }\end{array}$ & $\begin{array}{c}\text { Age of } \\
\text { TW (yrs) }\end{array}$ & $\begin{array}{c}\text { Age of } \\
\text { SL (yrs) }\end{array}$ & $\begin{array}{l}\text { SL } \\
\text { type }\end{array}$ & $\begin{array}{c}\text { Depth of } \\
\text { SL (ft) }\end{array}$ & $\begin{array}{l}\text { Distance of SL } \\
\text { to TW(ft) }\end{array}$ \\
\hline $\mathrm{T} 11$ & 160 & 5 & 12 & $\mathrm{RG}$ & 12.5 & 10 \\
\hline Т 12 & 160 & 31 & 11 & $\mathrm{RG}$ & 20 & 8 \\
\hline Т 20 & 75 & 10 & 4 & $\mathrm{RG}$ & 10 & 4 \\
\hline Т 29 & 90 & 10 & 10 & $\mathrm{RG}$ & 12.5 & 10 \\
\hline Т 33 & 105 & 5 & 12 & $\mathrm{RG}$ & 2 & 4 \\
\hline Т 34 & 120 & 2 & 2 & $\mathrm{RG}$ & 12.5 & 7 \\
\hline Т 36 & 100 & 15 & 3 & ST & 2 & 10 \\
\hline Т 59 & 180 & 12 & 10 & $\mathrm{RG}$ & 27.5 & 3 \\
\hline Т 60 & 180 & 12 & 12 & $\mathrm{RG}$ & 30 & 8 \\
\hline Т 88 & 175 & 5 & 3 & $\mathrm{RG}$ & 12 & 3 \\
\hline Т 89 & 90 & 4 & 5 & $\mathrm{RG}$ & 17.5 & 5 \\
\hline Т 90 & 120 & 6 & 7 & $\mathrm{RG}$ & 15 & 12 \\
\hline Т 91 & 120 & 7 & 6 & $\mathrm{OP}$ & 2 & 3 \\
\hline Т 92 & 100 & 6 & 5 & $\mathrm{RG}$ & 12 & 10 \\
\hline Т 93 & 150 & 4 & 2 & $\mathrm{RG}$ & 15 & 8 \\
\hline Т 94 & 180 & 6 & 4 & $\mathrm{OP}$ & 5 & 10 \\
\hline Т 95 & 120 & 7 & 9 & $\mathrm{RG}$ & 10 & 8 \\
\hline Т 96 & 120 & 8 & 6 & $\mathrm{RG}$ & 12 & 5 \\
\hline Т 97 & 150 & 5 & 3 & $\mathrm{RG}$ & 10 & 6 \\
\hline Т 98 & 130 & 3 & 7 & $\mathrm{RG}$ & 14 & 5 \\
\hline Т 99 & 100 & 7 & 5 & $\mathrm{RG}$ & 17 & 7 \\
\hline
\end{tabular}

TW: Tube well; SL: Sanitary latrine; OP: Open; RG: Ring slab; ST: Septic tank

Three different zones of distinct lithology were recognized from top to bottom in the study area. A summary of the zones marked as zone (1), zone (2) and zone (3) is given in 
Table 3 along with thickness of the subsurface geology. Cross-sections of the four boreholes, individual log (Fig. 2) and panel diagram (Fig. 3) indicate that silt was rich in southern side almost near the river and thinner in other sides. Silty clay was thick in eastern side but relatively thin in southern side and moderate in other side. This gave a scenario of alluvium deposition near the river. Almost $30 \mathrm{ft}$ thick sandy clay semipermeable layer was found in southern side. Below this layer some dark color peat layer was found. A large number of clay layers were found below the peat layer, which was thick in southern side and thin in other side. Some peaty clay was also found below the clay layer. It was thick in west side and thin in eastern side of the study area. A shallow aquifer was found at a depth of hundred feet from where local people extract drinking water.

Table 3. Thickness of four bore holes and properties of lithostratigrapic zones.

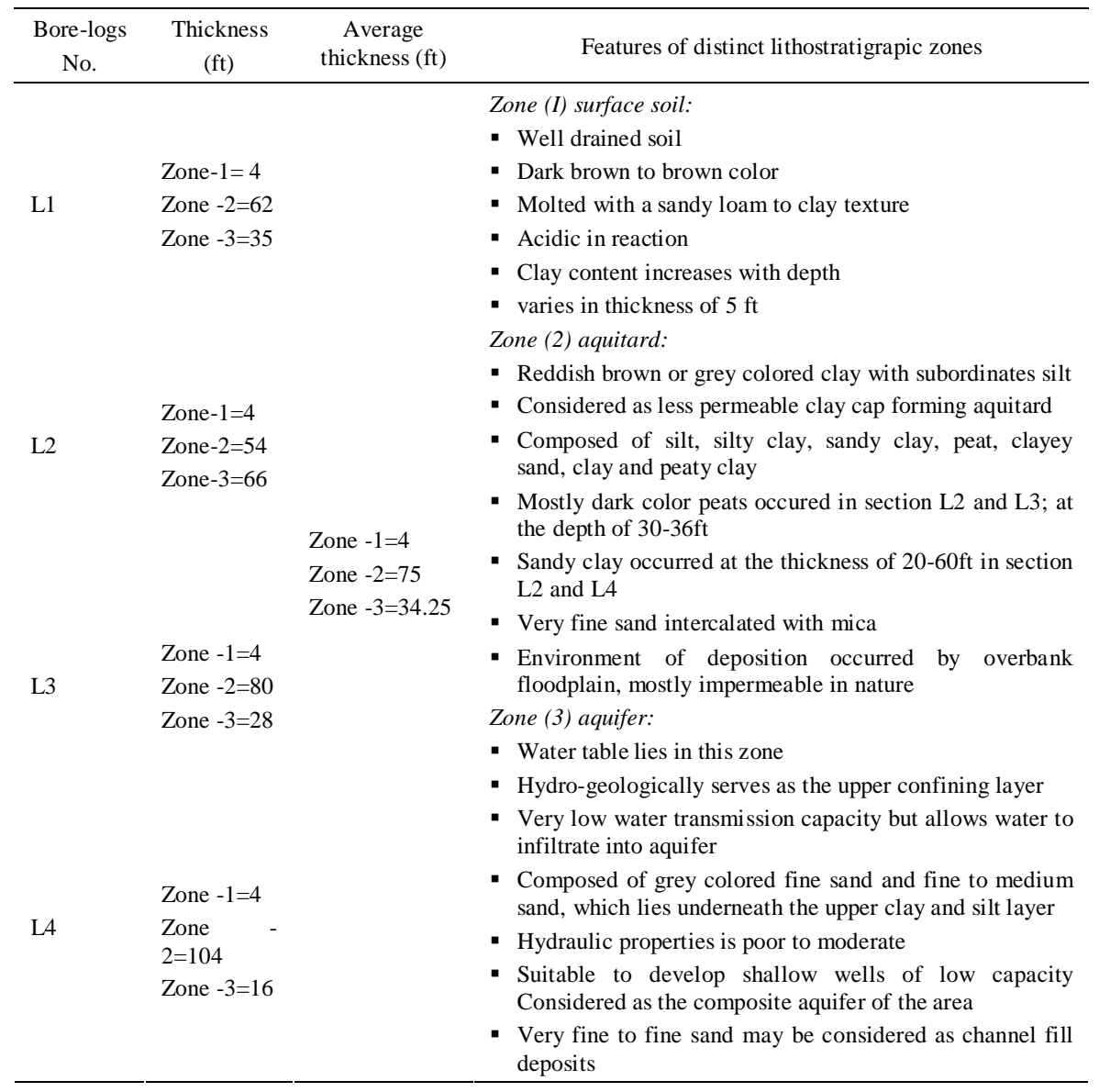




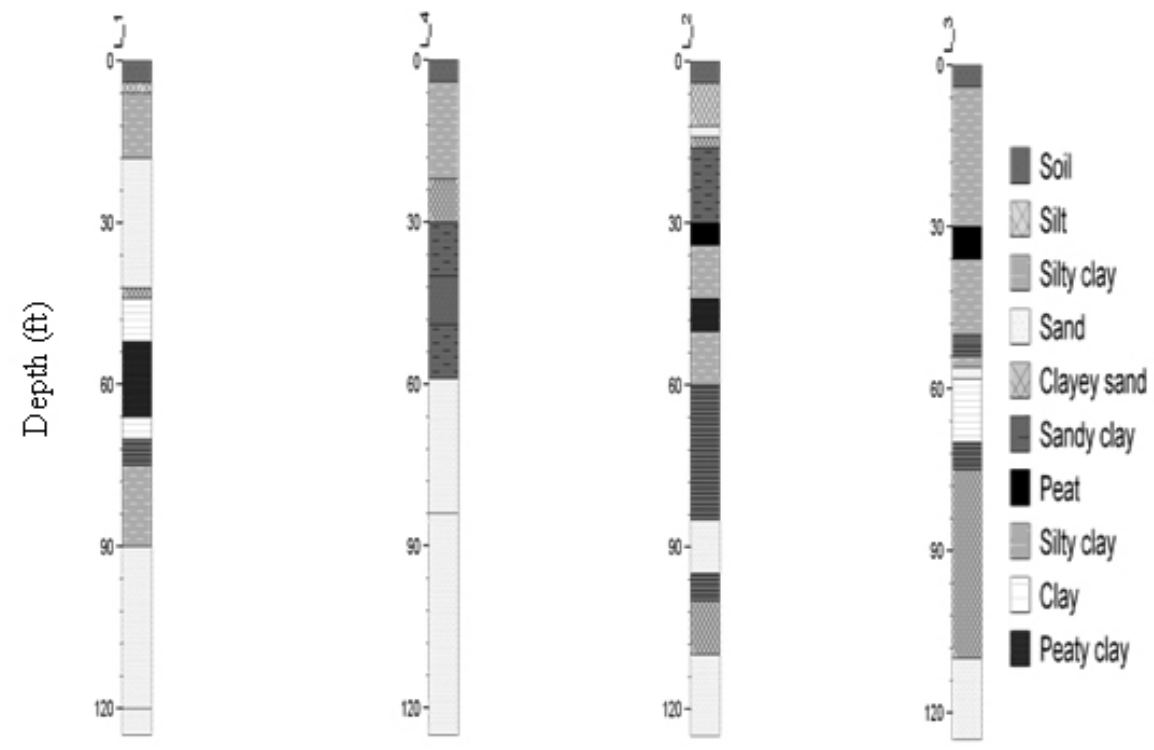

Fig. 2. Cross-sections of the boreholes.

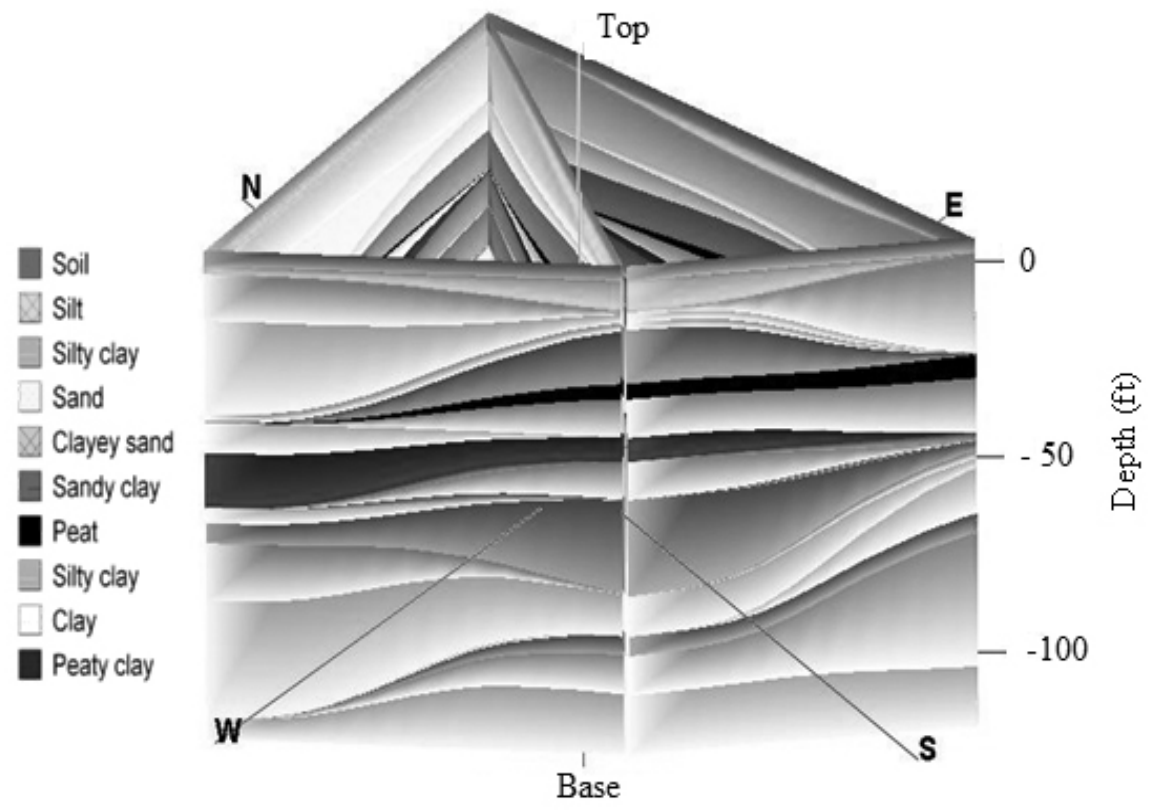

Fig. 3. Panel diagram of the study area.

Physico-chemical parameters of tube well water of the study area are given in Table 4. Tube well water $\mathrm{pH}$, sulphate, nitrate and nitrite were within the allowable limit of 
Department of Environment (DoE 2003) for drinking purpose. All the studied parameters showed an uneven distribution over the study area. Phosphate concentration did not comply with the standard recommended by DoE (2003). Almost similar trend was found in another village in Bangladesh by Rahman et al. (2009). Phosphate may arise from sanitary latrine situated just adjacent to the tube wells. Two tube wells exceed the highest permissible limit of iron (Fe) for drinking purpose. The correlation coefficient matrix among the physico-chemical parameters of sample water is given in Table 5. $\mathrm{NO}_{2}$ correlated positively with $\mathrm{pH}, \mathrm{Fe}$ and $\mathrm{NO}_{3}$, while negatively with $\mathrm{DO} . \mathrm{NO}_{3}$ also correlated positively with $\mathrm{pH}$ and negatively with $\mathrm{DO}$. $\mathrm{DO}$ and $\mathrm{pH}$ showed strong negative correlation.

Table 4. Physico-chemical parameters of shallow tube wells water of Shinduria village.

\begin{tabular}{|c|c|c|c|c|c|c|c|}
\hline Sample No. & $\mathrm{pH}$ & $\begin{array}{c}\mathrm{DO} \\
(\mathrm{ppm})\end{array}$ & $\begin{array}{c}\mathrm{PO}_{4} \\
(\mathrm{mg} / \mathrm{l})\end{array}$ & $\begin{array}{c}\mathrm{SO}_{4} \\
(\mathrm{mg} / \mathrm{l})\end{array}$ & $\begin{array}{c}\mathrm{NO}_{3} \\
(\mathrm{mg} / \mathrm{l})\end{array}$ & $\begin{array}{c}\mathrm{NO}_{2} \\
(\mathrm{mg} / \mathrm{l})\end{array}$ & $\begin{array}{c}\mathrm{Fe} \\
(\mathrm{mg} / \mathrm{l})\end{array}$ \\
\hline T11 & 7.09 & 4.07 & 0.7 & 7 & 1.0 & 0.064 & 0.21 \\
\hline $\mathrm{T} 12$ & 7.11 & 4.02 & 0.4 & 9 & 2.2 & 0.058 & 0.45 \\
\hline $\mathrm{T} 20$ & 6.97 & 4.13 & 0.2 & 14 & 0.9 & 0.072 & 1.06 \\
\hline $\mathrm{T} 29$ & 7.35 & 4.05 & 0.3 & 5 & 2.0 & 0.054 & 0.56 \\
\hline T33 & 7.01 & 4.14 & 0.5 & 24 & 0.7 & 0.023 & 0.45 \\
\hline T34 & 7.06 & 4.11 & 0.6 & 6 & 1.02 & 0.035 & 0.6 \\
\hline T36 & 6.92 & 4.16 & 0.5 & 5 & 1.18 & 0.026 & 0.15 \\
\hline T59 & 7.35 & 4.02 & 0.4 & 23 & 1.25 & 0.075 & 0.52 \\
\hline T60 & 7.35 & 4.07 & 0.5 & 5 & 2.0 & 0.087 & 1.3 \\
\hline T88 & 7.38 & 4.03 & 0.4 & 7 & 2.2 & 0.091 & 0.5 \\
\hline T89 & 7.03 & 4.15 & 1.3 & 5 & 1.6 & 0.021 & 0.4 \\
\hline T90 & 7.12 & 4.06 & 1.4 & 7 & 1.0 & 0.047 & 0.4 \\
\hline T91 & 7.27 & 4.02 & 0.8 & 7 & 2.1 & 0.075 & 0.7 \\
\hline T92 & 7.25 & 4.04 & 0.7 & 4 & 2.0 & 0.068 & 0.7 \\
\hline Т93 & 7.28 & 4.05 & 0.4 & 6 & 1.5 & 0.048 & 0.17 \\
\hline T94 & 7.03 & 4.14 & 0.5 & 7 & 1.0 & 0.037 & 0.62 \\
\hline T95 & 7.35 & 4.03 & 0.5 & 27 & 1.5 & 0.035 & 0.34 \\
\hline T96 & 6.97 & 4.17 & 0.4 & 9 & 1.3 & 0.033 & 0.53 \\
\hline T97 & 7.18 & 4.01 & 0.3 & 6 & 1.7 & 0.037 & 0.64 \\
\hline T98 & 7.25 & 4.11 & 0.9 & 6 & 1.2 & 0.049 & 0.2 \\
\hline T99 & 7.15 & 4.09 & 2.2 & 5 & 2.1 & 0.088 & 0.81 \\
\hline Minimum & 6.9 & 4.03 & 0.2 & 5 & 0.7 & 0.02 & 0.2 \\
\hline Maximum & 7.38 & 4.17 & 2.2 & 27 & 2.2 & 0.091 & 1.3 \\
\hline Mean & 7.18 & 4.07 & 0.66 & 9.24 & 1.50 & 0.054 & 0.54 \\
\hline SD & 0.15 & 0.05 & 0.47 & 6.82 & 0.45 & 0.02 & 0.28 \\
\hline DoE standard ${ }^{\mathrm{a}}$ & $6.5-8.5$ & 6 & 0.05 & 400 & 10 & $<1$ & $0.3-1.0$ \\
\hline
\end{tabular}

${ }^{a} \operatorname{DoE}$ (2003). 
Table 5. Correlation coefficient matrix among physico-chemical parameters of shallow tube wells water.

\begin{tabular}{lllccccc}
\hline & \multicolumn{1}{c}{$\mathrm{pH}$} & \multicolumn{1}{c}{$\mathrm{DO}$} & $\mathrm{PO}_{4}$ & $\mathrm{SO}_{4}$ & $\mathrm{NO}_{3}$ & $\mathrm{NO}_{2}$ & $\mathrm{Fe}$ \\
\hline $\mathrm{pH}$ & 1 & & & & & & \\
$\mathrm{DO}$ & $-.780^{* *}$ & \multicolumn{1}{c}{1} & & & & & \\
$\mathrm{PO}_{4}$ & -.091 & .121 & 1 & & & & \\
$\mathrm{SO}_{4}$ & .091 & -.082 & -.269 & 1 & & & \\
$\mathrm{NO}_{3}$ & $.584^{* *}$ & $-.580^{* *}$ & .135 & -.366 & 1 & & \\
$\mathrm{NO}_{2}$ & $.552^{* *}$ & $-.511^{*}$ & .138 & -.153 & $.545^{*}$ & 1 & \\
$\mathrm{Fe}$ & .118 & -.059 & -.006 & -.086 & .290 & $.532^{*}$ & 1 \\
\hline
\end{tabular}

** Correlation is significant at the $0.01 \%$ level (2-tailed), ${ }^{*}$ Correlation is significant at the $0.05 \%$ level (2-tailed)

Biological properties of any water system reflect the conditions existing in the environment. Bacteriological quality of tube well water of the study area is illustrated in Table 6. TVBC ranged from $6.12 \times 10^{2}$ to $1.076 \times 10^{4} \mathrm{cfu} / 100 \mathrm{ml}$. The results suggested that the bacteriological qualities of the water sources were unacceptable for drinking purposes. Luby et al. (2008) also found high range of bacteriological load in tube well water in three flood-prone areas of Bangladesh. TCC include bacteria that occur naturally in the intestines of warm-blooded animals. So, presence of this group in the groundwater was an indicator of microbial pollution from human feces source. This also indicated the possibility of the presence of other pathogenic microorganisms as well as contamination of the water source with sewage (Hosetti and Kumar 2002). TCC ranged from $1.5 \times 10^{1}$ to $4.98 \times 10^{3} \mathrm{cfu} / 100 \mathrm{ml}$ in water samples and values exceeded the maximum recommended limit set by WHO (2004) for drinking water. Hence, drinking of such water can pose a serious health risk to the consumers. The highest TCC was found in tube wells located within $5 \mathrm{ft}$ of a ring slab latrine. So, there was a strong possibility of contamination of groundwater by microbes from human faecal origin. Rahman et al. (2009) found total coliform bacteria as 0 to $15 \mathrm{cfu} / 100 \mathrm{ml}$ in a rural area of Bangladesh and unsafe latrine was the main contribution of such pollution. TCC ranged from $1.18 \times 10^{3}$ to $4.9 \times 10^{4}$ cfu/100 ml in Lefatlheng well water, and $2.1 \times 10^{3} \mathrm{cfu} / 100 \mathrm{ml}$ in Thaloganyo groundwater, South Africa (DWAF 1996). Islam et al. (2001) found total coliform $/ 100 \mathrm{ml}$ tube well water as $1.7 \times 10^{1}$ in Chandpur district, Bangladesh, where unsafe latrine was found as prime cause of such contamination. TFCC should be absent in the drinking water because it indicates presence of pathogens due to faecal contamination (Schmoll et al. 2006). In the present study, TFCC ranged from 0.0 to $3.49 \times 10^{3} \mathrm{cfu} / 100 \mathrm{ml}$. There is a significant and increasing risk of infectious disease transmission. Laluraj et al. (2005) also found high TFCC in the tube wells nearby sanitary sources. Faecal contamination of groundwater results from a complex interactions among faecal pollution on the surface, suboptimal sanitary construction, temperature, moisture, soil type, pore size, flow rate, organic carbon content, $\mathrm{pH}$, salinity, predation and the concentration, type and size of specific pathogens (Schmoll et al. 2006). Salmonella spp. was found in most of the 
studied tube wells. No Vibrio cholerae was identified from any of the samples analyzed. Status of TVBC, TCC, TFCC and TSS in the shallow tube wells was much higher than WHO (2004) recommended standard (Nil) for drinking water. TVBC was positively correlated with TSS, TFCC and TCC while TCC was positively correlated with TSS and TFCC (Table 7).

Table 6. Quantitative analysis of different bacteriological load in shallow tube wells water.

\begin{tabular}{|c|c|c|c|c|c|}
\hline Sample No. & TVBC $/ 100 \mathrm{ml}$ & $\mathrm{TCC} / 100 \mathrm{ml}$ & $\mathrm{TFCC} / 100 \mathrm{ml}$ & $\mathrm{TSS} / 100 \mathrm{ml}$ & $\mathrm{TVC} / 100 \mathrm{ml}$ \\
\hline $\mathrm{T} 11$ & $2.0 \times 10^{3}$ & $2.48 \times 10^{3}$ & $2.6 \times 10^{1}$ & $2.1 \times 10^{1}$ & Nil \\
\hline $\mathrm{T} 12$ & $1.60 \times 10^{3}$ & $2.3 \times 10^{1}$ & $1.7 \times 10^{1}$ & $1.6 \times 10^{1}$ & Nil \\
\hline $\mathrm{T} 20$ & $6.12 \times 10^{2}$ & $1.5 \times 10^{1}$ & Nil & Nil & Nil \\
\hline $\mathrm{T} 29$ & $1.58 \times 10^{3}$ & $2.91 \times 10^{3}$ & $1.83 \times 10^{2}$ & Nil & Nil \\
\hline $\mathrm{T} 33$ & $5.59 \times 10^{3}$ & $3.47 \times 10^{3}$ & $5.44 \times 10^{2}$ & $4.88 \times 10^{2}$ & Nil \\
\hline $\mathrm{T} 34$ & $4.55 \times 10^{3}$ & $1.50 \times 10^{3}$ & $4.49 \times 10^{3}$ & $2.46 \times 10^{2}$ & Nil \\
\hline $\mathrm{T} 36$ & $7.87 \times 10^{3}$ & $7.97 \times 10^{3}$ & $1.78 \times 10^{2}$ & $3.19 \times 10^{3}$ & Nil \\
\hline T59 & $2.88 \times 10^{3}$ & $4.73 \times 10^{2}$ & $1.60 \times 10^{2}$ & $8.9 \times 10^{1}$ & Nil \\
\hline T60 & $3.87 \times 10^{3}$ & $5.69 \times 10^{2}$ & $3.27 \times 10^{2}$ & Nil & Nil \\
\hline $\mathrm{T} 88$ & $5.72 \times 10^{3}$ & $17.0 \times 10^{3}$ & $6.20 \times 10^{2}$ & $1.41 \times 10^{3}$ & Nil \\
\hline T89 & $2.89 \times 10^{3}$ & $2.57 \times 10^{3}$ & $5.1 \times 10^{1}$ & $8.6 \times 10^{1}$ & Nil \\
\hline T90 & $8.80 \times 10^{3}$ & $8.40 \times 10^{2}$ & $1.18 \times 10^{2}$ & $7.2 \times 10^{1}$ & Nil \\
\hline T91 & $6.17 \times 10^{3}$ & $5.93 \times 10^{3}$ & $7.60 \times 10^{2}$ & $8.40 \times 10^{2}$ & Nil \\
\hline T92 & $4.77 \times 10^{3}$ & $5.18 \times 10^{3}$ & $3.49 \times 10^{3}$ & $3.70 \times 10^{2}$ & Nil \\
\hline T93 & $5.78 \times 10^{3}$ & $2.23 \times 10^{3}$ & $7.28 \times 10^{2}$ & $2.90 \times 10^{2}$ & Nil \\
\hline T94 & $6.35 \times 10^{3}$ & $7.59 \times 10^{3}$ & $2.24 \times 10^{2}$ & $9.6 \times 10^{2}$ & Nil \\
\hline T95 & $1.048 \times 10^{4}$ & $3.26 \times 10^{4}$ & $1.380 \times 10^{3}$ & $1.3 \times 10^{3}$ & Nil \\
\hline T96 & $5.21 \times 10^{3}$ & $1.070 \times 10^{3}$ & $2.70 \times 10^{2}$ & $2.32 \times 10^{2}$ & Nil \\
\hline T97 & $4.4 \times 10^{3}$ & $1.718 \times 10^{4}$ & $1.006 \times 10^{3}$ & $1.46 \times 10^{2}$ & Nil \\
\hline T98 & $1.076 \times 10^{4}$ & $4.981 \times 10^{4}$ & $1.3 \times 10^{2}$ & $2.358 \times 10^{3}$ & Nil \\
\hline T99 & $4.74 \times 10^{3}$ & $1.552 \times 10^{4}$ & $2.42 \times 10^{2}$ & $1.06 \times 10^{2}$ & Nil \\
\hline Minimum & $6.12 \times 10^{2}$ & $1.5 \times 10^{1}$ & Nil & Nil & Nil \\
\hline Maximum & $1.076 \times 10^{4}$ & $4.98 \times 10^{3}$ & $3.49 \times 10^{3}$ & $2.35 \times 10^{3}$ & Nil \\
\hline Mean & $5.07 \times 10^{3}$ & $8.44 \times 10^{3}$ & $5.16 \times 10^{2}$ & $1.10 \times 10^{3}$ & Nil \\
\hline $\begin{array}{c}\text { WHO } \\
\text { Standard }^{\mathrm{b}}\end{array}$ & Nil & Nil & Nil & Nil & Nil \\
\hline
\end{tabular}

${ }^{\mathrm{b}}$ WHO (2004).

The Bangshi River is flowing along the north to south direction (Fig.1) that played a vital role recharging the aquifer. Hence, the groundwater flow direction in the study area is from west to east. If latrines were counted as constant regards to tube wells, it gave an 
idea about the possible contamination by groundwater flow. Out of 21 tube wells, 13 were located in the eastern side which shows more microbial contamination than other eight tube wells located in the western side of the open pit latrines. Moreover, proximity of tube wells and latrines ( $<10 \mathrm{ft})$ might be another cause of microbial contamination in the western side tube wells in the study area (Rahman et al. 2009). van Geen et al. (2011) also identified latrine as a plausible proxy for microbial contamination of tube well.

Table 7. Correlation coefficient matrix among microbial communities of water samples.

\begin{tabular}{lcccc}
\hline & TVBC & TCC & TFCC & TSS \\
\hline TBC & 1 & & & \\
TC & $682^{* *}$ & 1 & & \\
TFCC & $.578^{* *}$ & $.819^{* *}$ & 1 & 1 \\
TSS & $.683^{* *}$ & $.600^{* *}$ & .431 & 1 \\
\hline
\end{tabular}

**Correlation is significant at the $0.01 \%$ level (2-tailed), * Correlation is significant at the $0.05 \%$ level (2-tailed)

During rainy season river water overflow the study area and human wastes of open pit latrines spread out which contain large numbers of enteric microorganisms that have high concentrations of nutrients and a high oxygen demand, all of which may have an adverse impact on groundwater quality. Polluted water might enter through well head if it is not fully sealed with protected layer. Water application rates temporarily exceed the hydraulic conductivity of soils, such as during intense rainstorms, or where septic tanks may overflow, solutes are readily leached by preferential flow in sandy soils. Moreover, fecal contaminants may infiltrate to the aquifer and occasional contamination of well water might occur due to backflow from the tube well. Some microbes can be transported through sand and small fraction of bacteria do not attach to the sediment (Mailloux et al. 2003, Taylor et al. 2004, Foppen and Schijven 2006).

\section{CONCLUSION}

Improper sanitary latrines are supposed to be one of the sources in rural Bangladesh where latrines are closely located to shallow tube wells. Local geomorphology, lithostratigraphy and groundwater flow also influence microbial contamination of shallow aquifer. It can be concluded that latrines influence microbial contamination of adjacent tube well water where aquifer flow direction is from latrine to tube well. In the study area tube well should be located at western side of the latrine and the distance between them should be more than $10 \mathrm{ft}$ to avoid the possibility of microbial contamination. Therefore, information on local lithology and groundwater flow direction should be considered during new shallow tube well installation in any rural area of Bangladesh adjacent to pit latrine. 


\section{ACKNOWLEDGEMENT}

Authors are grateful to the Ministry of Science and Information \& Communication Technology, Government of the People's Republic of Bangladesh for financial assistance.

\section{REFERENCES}

Anand, C., P. Akolkar and R. Chakrabarti. 2006. Bacteriological water quality status of river Yamuna in Delhi. J. Environ. Bio. 27: 97-107.

Blueford, M., B. D. Lindsey and M. S. Beaveer. 1996. Bacteriological quality of groundwater used for household supply. USGS Water Resources Investigation Report, 4212.

Craun, G. F., P. S. Berger and R. L. Calderon. 1997. Coliform bacteria and waterborne disease outbreaks. J. Am. Water Works Asso. 89: 96-104.

de Andrade, E. M., M. Palacio, H. A. Souza, I. H. de Oliveira, R. A. Leaoand M. J. Guerreiro. 2008. Land use effects in groundwater composition of an alluvial aquifer (Trussu River, Brazil) by multivariate techniques. Environ. Res. 106: 170-177.

DoE (Department of Environment). 2003. A compilation of Environmental Laws, Department of Environment and Bangladesh Management Project. Schedule 10.

DWAF (Department of Water Affairs and Forestry). 1996. South African Water Quality Guidelines for Domestic Use, $2^{\text {nd }}$ Edition, Pretoria, South Africa.

Dwivedi, U. N., S. Mishra, P. Singh and R. D. Tripathy. 2007. Nitrate pollution and its remediation.In Environmental bioremediation technologies.(Edited by Singh SN and Tripathy RD). Springer: Berlin, pp. 353-389.

Foppen, J. W. A. and J. F. Schijven. 2006. Evaluation of data from the literature on the transport and survival of Escherichia coli and thermotolerant coliforms in aquifers under saturated conditions. Water Res. 40(3): 401-426.

Hosetti, B. B. and A. Kumar. 2002. A Textbook of Applied Aquatic Biology. Daya Publishing House, Delhi. pp. 35.

Islam, M. S., A. Siddika, M. N. H. Khan, M. M. Goldar, M. A. Sadique,A. N. M. H. Kabir, A. Huq andR. R. Colwell. 2001. Microbiological Analysis of Tube-Well Water in a Rural Area of Bangladesh. Appl. Environ. Micro. 67: 3328-3330.

Jones, F. and J. Watkins. 1985. The water cycle as a source of pathogens. J. Appl. Micro. 59: 27-36.

Khandoker, R. A. 1987. Origin of elevated Barind-Madhupur areas, Bengal Basin: Result of Neotectonic Activities. Bangladesh J. Geol. 6: 1-9.

Krishnan, R. R, K. Dharmaraj and B. D. R. Kumari. 2007. A comparative study on the physicochemical and bacterial analysis of drinking, borewell and sewage water in the three different places of Sivakasi. J. Environ. Bio. 28: 105-108.

Laluraj, C. M., G. Gopinath and P. K. Dineshkumar. 2005. Groundwater Chemistry of Shallow Aquifers in the Coastal Zones of Cochin, India. App. Eco. Environ. Res. 3: 133-139.

Luby, S., M. S. Islam and R. Johnston. 2006. Chlorine spot treatment of flooded tube wells, an efficacy trial. J. Appl. Micro. 100: 1154-1158.

Luby, S. P., S. K. Gupta, M. A. Sheikh, R. B. Johnston, P. K. Ram and M. S. Islam. 2008. Tubewell water quality and predictors of contamination in three flood-prone areas in Bangladesh. Soc. App. Micro. 105: 1002-1008.

Mailloux, B. J., M. E. Fuller, T. C. Onstott, J. Hall, H. Dong, M. F. DeFlaun, S. H. Streger, R. K. Rothmel, M. Green, D. J. P. Swift and J. Radke. 2003. The role of physical heterogeneity on the field-scale transport and attachment of bacteria. Water Resour. Res. 39: 1142-1158. 
NIPORT. 2005. Bangladesh Demographic and Health Survey. Dhaka, Bangladesh and Calverton, MD, USA: National Institute of Population Research and Training, Mitra and Associates, Dhaka, Bangladesh.

Ozler, H. M. and A. Aydin. 2008. Hydrochemical and microbiological quality of groundwater in West Thrace Region of Turkey. Environ. Geol. 54: 355-363.

Rahman, S. H., S. Ahmed and M. Zakariya. 2009. Investigation of shallow tube-well water quality considering the influence of nearby latrines in a rural village of Bangladesh. Trends and Sustainability of Groundwater in Highly Stressed Aquifers, In: Proceeding of Symposium JS. 2 at the Joint IAHS and IAH Convention, Hyderabad, India, IAHS Publishers; 329.

Schmoll, O., G. Howard, J. Chilton and I. Chorus. 2006. Protecting groundwater for health: Managing the quality of drinking water sources. WHO/IWA, London, UK. pp. 1-663.

Taylor, R., A. Cronin, S. Pedley, J. Barker and T. Atkinson. 2004. The implications of groundwater velocity variations on microbial transport and wellhead protection: Review of field evidence. FEMS Microbiol. Ecol. 49: 17-26.

van Geen, A., K. M. Ahmed, Y. Akita, M. J. Alam, P. J. Culligan, M. Emch, V. Escamilla, J. Feighery, A. S. Ferguson, P. Knappett, A. C. Layton, B .J. Mailloux, L. D. McKay, J. L. Mey, M .L. Serre, P. K. Streatfield, J. Wu and M. Yunus. 2011. Fecal Contamination of Shallow Tubewells in Bangladesh Inversely Related to Arsenic. Environ. Sci. Techno. 45: 1199-1205.

WHO (World Health Organization). 2004. Guidelines for Drinking-water quality, Volume 1: Recommendations, World Health Organization, Geneva, pp. 296-460.

(Received revised manuscript on 25 September, 2013) 